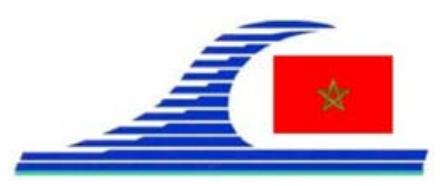

Conférence Méditerranéenne Côtière et Maritime

EDITION 2, TANGER, MAROC (2011)

Coastal and Maritime Mediterranean Conference

Disponible en ligne - http://www.paralia.fr-Available online

\title{
Durability analysis of fly ash/cement-solidified dredged materials
}

\section{Dongxing WANG ${ }^{1,2}$, Nor Edine ABRIAK ${ }^{1}$, Rachid ZENTAR ${ }^{1}$}

1. Civil and Environmental Engineering Department, Ecole des Mines de Douai, 59508 Douai, France.

2. Geotechnical Research Institute, HoHai University, 210098 Nanjing, China. dongxing.wang@mines-douai.fr

\begin{abstract}
:
Solidified dredged materials as construction materials are increasingly popular because of their better mechanical performance and low pollution. Based on their physical characteristics, a series of tests, such as unconfined compressive strength tests, water immersion tests and thawing-freezing tests, were performed to explore the durability of fly ash/cement-treated sediments. For solidified samples immersed in water for 4 days, the I-CBR index increases while the corresponding compressive strength of cylindrical samples after 32-day water immersion decreases. For sediment samples subjected to thawing-freezing cycles, the compressive strength decreases due to the weakening effect of water on the bonding established by calcium silicate hydrate.
\end{abstract}

\section{Keywords:}

Dredged material - Fly ash - Cement - I-CBR - Unconfined compressive strength Water immersion test - Thawing-freezing test

\section{Introduction}

Usually, dredged materials are soft soils which have low shear strengths $\left(\mathrm{c}_{\mathrm{u}}<50 \mathrm{kPa}\right)$, and natural water contents higher than their liquid limits (CHIU et al., 2008). Furthermore, dredged materials may be contaminated with certain types of organic compounds and heavy metals. Binders, such as cement and fly ash, could be added to stabilize and solidify various soils and sediments to improve one, or all, of the following properties: strength, contaminant leachability, workability or resistance to $\mathrm{pH}$ changes (DERMATAS \& MENG, 2003; BAHAR et al., 2004; SEZER et al., 2006).

Fly ash is defined as the finely divided residue resulting from the combustion of ground or powdered coal in a power station. Owing to its pozzolanic nature and low cost, the majority of fly ash can be used in several domains, such as cement and concrete products, and raw materials for embankment and road base. Class F fly ash (very low contents in $\mathrm{CaO}$ ) is not self-cementitious by itself, and therefore, should be mixed with a stabilizing agent such as cement to activate its pozzolanic reactivity. Fly ash used as a 
La connaissance de la Mer:

un vecteur du développement durable en Méditerranée

base or sub-layer material for road pavement has been explored in several studies (OBERST, 1985; LAV \& KENNY, 1996).

The present work focuses on the durability properties of Dunkirk dredged sediments solidified with fly ash and cement. The main purposes are to: (1) explore the change in I-CBR index after immersion in water for 4 days, (2) investigate the compressive strength of solidified sediments after water immersion for 32 days and (3) study the change in compressive strength of solidified sediments after 20 freezing-thawing cycles.

\section{Studied materials}

For the dredged materials from the East Port of Dunkirk, the physical characterization is reported in Table 1 . The initial water content, measured by an oven at $40^{\circ} \mathrm{C}$, is $129.9 \%$. The specific density measured by a helium pycnometer is $2.53 \mathrm{~g} / \mathrm{cm}^{3}$, and the blue methylene value is $3.1 \mathrm{~g} / 100 \mathrm{~g}$. The organic matter content is about $6.27 \%$, determined by the ignition test at $450^{\circ} \mathrm{C}$. The grain size distribution of dredged sediments is obtained by laser technique, and the fractions of clay, silt and sand are $14.5 \%, 74.7 \%$ and $10.8 \%$. The liquid limit is $76.1 \%$, determined by the percussion cup test, and the plastic limit is $35.3 \%$, by the rolling thread test.

Table 1. Basic characteristics of dredged sediments.

\begin{tabular}{|c|c|c|}
\hline \multicolumn{2}{|l|}{ Parameters } & Values \\
\hline \multicolumn{2}{|c|}{ Water content (\%) } & 129.9 \\
\hline \multicolumn{2}{|c|}{ Specific density $\left(\mathrm{g} / \mathrm{cm}^{3}\right)$} & 2.53 \\
\hline \multicolumn{2}{|c|}{ Blue methylene value $(\mathrm{g} / 100 \mathrm{~g})$} & 3.1 \\
\hline \multicolumn{2}{|c|}{ Organic matter content (\%) } & 6.27 \\
\hline \multirow{3}{*}{$\begin{array}{l}\text { Particle size } \\
\text { distribution (\%) }\end{array}$} & Particles $<2 \mu m$ & 14.5 \\
\hline & $2 \mu m<$ Particles $<63 \mu m$ & 74.7 \\
\hline & Particles $>63 \mu \mathrm{m}$ & 10.8 \\
\hline \multicolumn{2}{|l|}{ Liquid limit (\%) } & 76.1 \\
\hline \multicolumn{2}{|l|}{ Plastic limit (\%) } & 35.3 \\
\hline
\end{tabular}

Cement CEM I 42.5R HSR LA (Cibelcor) is used as hydraulic binder, which contains $63.3 \% \mathrm{CaO}, 21.4 \% \mathrm{SiO}_{2}, 4.0 \% \mathrm{Fe}_{2} \mathrm{O}_{3}, 3.3 \% \mathrm{Al}_{2} \mathrm{O}_{3}, 2.4 \% \mathrm{MgO}, 2.8 \% \mathrm{SO}_{3}$ and $3.28 \%$ of other components. This cement can effectively resist the invasion of sulphate in marine sediments.

The used fly ash SILICOLINE®SECHE is classified as class F fly ash, and the main chemical elements in fly ash are $\mathrm{SiO}_{2}(50 \%), \mathrm{Fe}_{2} \mathrm{O}_{3}(8.5 \%)$ and $\mathrm{Al}_{2} \mathrm{O}_{3}(29 \%)$, but the amount of free $\mathrm{CaO}$ is $0.15-1 \%$ by dry weight. 


\section{Experimental program}

\subsection{Unconfined compressive strength tests}

All the cylindrical samples with a diameter of $50 \mathrm{~mm}$ and a height of $100 \mathrm{~mm}$ were prepared at the optimum moisture content $\rho_{\text {opt }}$ and at the optimum dry density $\omega_{\text {opt }}$ defined by modified Proctor test. The samples were cured under sealed conditions in a specified room with a constant temperature of $20^{\circ} \mathrm{C}$ and an average relative humidity of $98 \%$. The testing facilities used for unconfined compressive strength tests of samples is a press machine named INSTRON 5500R 4206-006.

\subsection{Water immersion test}

Water immersion tests in laboratory are appropriate to simulate attack of complex wet weather or rainy weather, where large amounts of water filter into the samples. The I-CBR immersion tests were carried out according to the standard NF P94-078 (1992) in standard one dimensional CBR mould with a radius of $76 \mathrm{~mm}$. The samples were prepared using Modified Proctor compaction test, and a pre-loading pressure of $2.8 \mathrm{kPa}$ was imposed on compacted samples immersed in water for 4 days.

For cylindrical samples with a diameter of $50 \mathrm{~mm}$ and a height of $100 \mathrm{~mm}$, after a curing period of 28 days at a temperature of $20^{\circ} \mathrm{C}$ and an average relative humidity of $98 \%$, the samples were immersed in water for 32 days. And then, the samples having endured water immersions were tested to determine unconfined compressive strength.

\subsection{Thawing-freezing test}

Closed system freezing was applied for thawing-freezing tests, and each sample after a curing period of 28 days was covered by a membrane. The samples were allowed to thaw at a temperature of $+10^{\circ} \mathrm{C}$ for 4 hours. After a fall of temperature from $+10^{\circ} \mathrm{C}$ to $-10^{\circ} \mathrm{C}$ in 4 hours, the samples were subjected to freezing temperature of $-10^{\circ} \mathrm{C}$ for 14 hours. After a rise of temperature from $-10^{\circ} \mathrm{C}$ to $+10^{\circ} \mathrm{C}$, the samples entered another cycle. All samples were subjected to 20 cycles of thawing-freezing.

\section{Results}

\subsection{Determination of compaction parameters}

The compaction parameters of solidified sediments determined by the Modified Proctor tests according to the Standard NF P94-093 (1993) are given in Table 2. All cylindrical samples are prepared at maximal dry density and optimal water content. The increase in fly ash quantity causes a small increase of maximal dry density $\left(\rho_{\text {opt }}\right)$ and optimal water content $\left(\omega_{\text {opt }}\right)$, but the increase in cement content leads to a decrease of $\rho_{\text {opt }}$ and $\omega_{\text {opt }}$. (SD: sediment, FA: fly ash, CEM: cement). 
La connaissance de la Mer :

un vecteur du développement durable en Méditerranée

Table 2. Compaction parameters for preparation of cylindrical samples.

\begin{tabular}{lll}
\hline Materials & $\boldsymbol{\rho}_{\text {opt }}\left(\mathbf{g} / \mathbf{c m}^{3}\right)$ & $\boldsymbol{\omega}_{\text {opt }}(\%)$ \\
\hline$S D+3 \% F A+3 \%$ CEM & 1.570 & 20.7 \\
$S D+3 \% F A+6 \%$ CEM & 1.561 & 20.4 \\
$S D+6 \% F A+3 \%$ CEM & 1.573 & 20.8 \\
\hline
\end{tabular}

4.2 I-CBR index after immersion in water for 4 days

The change in I-CBR index of solidified sediments with fly ash and cement is shown in Table 3. I-CBR index after immersion for 4 days is increased significantly due to the cement hydration reaction, and all the increased ratios (I-CBR after immersion divided by I-CBR before immersion) are higher than 1.0. The I-CBR value after immersion increases obviously as the increase in cement content, but it changes inconsiderably with the increase in fly ash content. Concerning hydration of cement with water, more $\mathrm{C}-\mathrm{S}-\mathrm{H}$ gels are formed and can ameliorate the microstructure increasing the bearing capacity of treated sediments.

Table 3. Change in I-CBR index after immersion test.

\begin{tabular}{llll}
\hline Materials & $\begin{array}{l}\text { I-CBR before } \\
\text { immersion (\%) }\end{array}$ & $\begin{array}{l}\text { I-CBR after } \\
\text { immersion (\%) }\end{array}$ & Ratio \\
\hline$S D+3 \% F A+3 \% C E M$ & 35.5 & 48.3 & 1.4 \\
$S D+3 \% F A+6 \% C E M$ & 25.8 & 73.3 & 2.8 \\
$S D+6 \% F A+3 \% C E M$ & 31.5 & 50.6 & 1.6 \\
\hline
\end{tabular}

4.3 Compressive strength $R c$ after immersion in water for 32 days

The average compressive strength $R_{c}$ for all solidified samples before and after immersion in water for 32 days is shown in Fig. 1 . The $R_{c}$ before immersion is obtained based on samples cured at 28 days.

Compared with sediments treated with 3\% fly ash and 3\% cement, the increase in cement content can considerably increase $R_{c}$ due to the formation of C-S-H gel, but the increase in fly ash content can not induce an obvious change in $R_{c}$. Larger fly ash contents lead to worse effects on strength, and this phenomenon results from the incorporation of more fine particles and unburned carbon in fly ash. Particularly, $R_{c}$ after immersion decreases considerably compared to $R_{c}$ before immersion, primarily due to the weakening effect of water on bonding between cement paste and sediment matrix.

\subsection{Compressive strength $R c$ after thawing-freezing cycles}

The compressive strength $R_{c}$ for all solidified samples before and after 20 cycles of thawing-freezing is shown in Fig. 2. A similar trend can be found by comparing the variation of $R_{c}$ of solidified sediments after immersion in water, but $R_{c}$ for each sample 
subjected to thawing-freezing cycles is much lower than $R_{c}$ of samples immersed in water. Thawing-freezing cycles can weaken the bonding established by $\mathrm{CSH}$ between cement grains and sediments particles. For sediments having suffered from thawing-freezing damage, the transformation between water and ice at different temperatures is the main factor weakening the C-S-H link. This transformation leads in part to irreversible changes in pore volume, and destroys the soil structure.

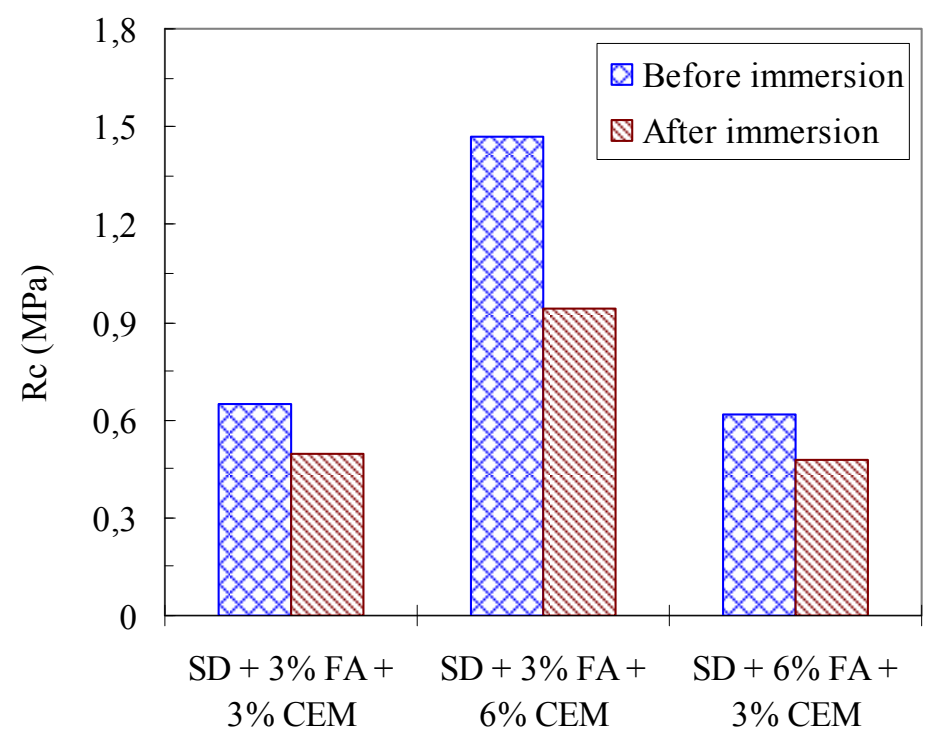

Figure 1. Comparison of $R_{c}$ before and after immersion in water for 32 days.

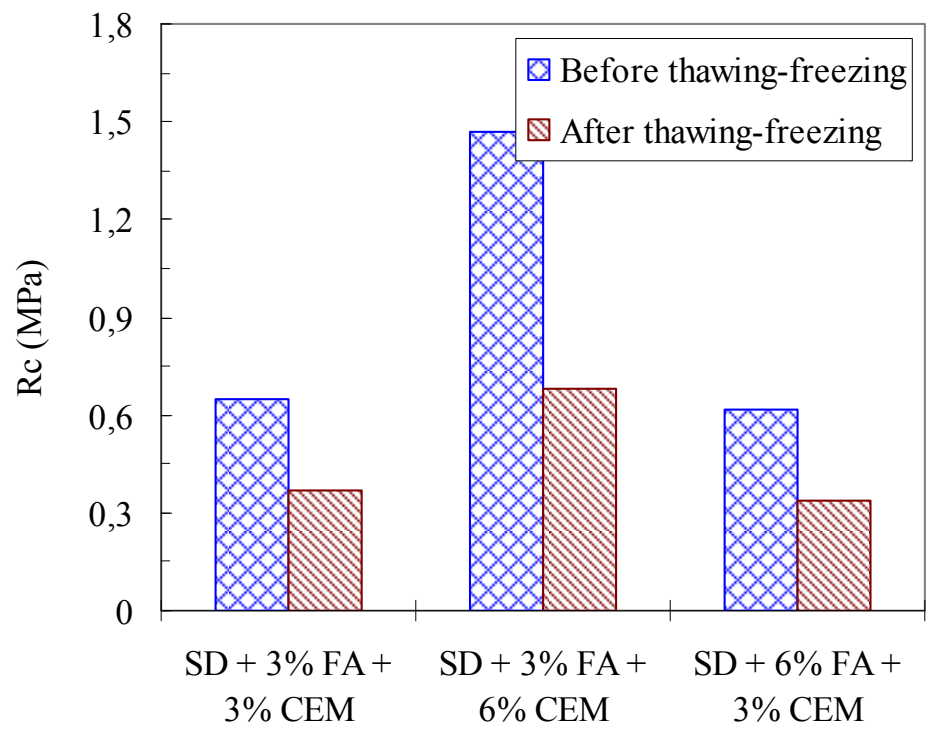

Figure 2. Comparison of $R_{c}$ before and after thawing-freezing cycles. 
La connaissance de la Mer :

un vecteur du développement durable en Méditerranée

\section{Conclusion}

This study gives the durability analysis of fly ash/cement solidified by Dunkirk-dredged materials for road construction. For the immersion test, the I-CBR index of solidified sediments after immersion increases considerably due to cement hydration. The compressive strength decreases evidently due to the weakening effect of water on bonding material C-S-H. In terms of solidified samples subjected to thawing-freezing cycles, a similar variation trend can be found and the compressive strength also decreases. Compared to sediments treated with 3\% fly ash plus 3\% cement, the increase in cement content can induce the increase of compressive strength while the increase in fly ash content cannot obviously change the compressive strength.

\section{Acknowledgement}

This research was undertaken with the financial support of China Scholarship Council.

\section{References}

BAHAR R., BENAZZOUG M., KENAI S. (2004). Performance of compacted cement-stabilised soil. Cement and Concrete Composites, Vol. 26, pp 811-820. doi:10.1016/j.cemconcomp.2004.01.003

CHIU C.F., ZHU W., ZHANG C.L. (2008). Yielding and shear behaviour of cement-treated dredged materials. Engineering Geology, Vol. 103, pp 1-12. doi:10.1016/j.enggeo.2008.07.007

DERMATAS D., MENG X.G. (2003). Utilization of fly ash for stabilization/solidification of heavy metal contaminated soils. Engineering Geology, $\mathrm{n}^{\circ}$ 70, pp 377-394. doi:10.1016/S0013-7952(03)00105-4

LAV A.H., KENNY P.J. (1996). Utilization of eraring (NSW) power plant fly ash as pavement base material. Seventh Australia New Zealand conference on geomechanics, Adelaide, pp 655-660.

NF P94-078 (1992). Soils: investigation and tests - CBR after immersion - Immediate $C B R$ - Immediate bearing ratio - Measurement on sample compacted in CBR mould.

NF P94-093 (1993). Soils: Investigation and testing - Determination of the compaction characteristics of a soil - Standard Proctor test - Modified Proctor test.

OBERST D.C. (1985). Cement-stabilized fly ash road bas. Proceedings of seventh international ash utilization symposium, $\mathrm{n}^{\circ} 2$, pp 590-596.

SEZER A., INAN G., YILMAZ H.R., RAMYAR K. (2006). Utilization of a very high lime fly ash for improvement of Izmir clay. Building and Environment, $\mathrm{n}^{\circ} 41$, pp 150-155. doi:10.1016/j.buildenv.2004.12.009 